\title{
Reproductive rates and periodicities of oceanic tintinnine ciliates
}

\author{
John F. Heinbokel* \\ Chesapeake Bay Institute, The Johns Hopkins University, Shady Side, Maryland 20764, USA
}

\begin{abstract}
Tintinnine ciliates from 3 strata $(40 \mathrm{~m}$ increments from the surface to $120 \mathrm{~m}$ depth) at a station in the oceanic North Pacific Ocean were sampled repeatedly through the day during a cruise in August-September 1984. Fourteen species were encountered in sufficient numbers to allow analysis of their diel periodicity and rates of reproduction. Species in the upper 2 strata $(0$ to $40 \mathrm{~m}, 40$ to $80 \mathrm{~m}$ ) consistently displayed 'clear' or 'probable' diel periodicity in division: division peaks occurred either near midnight (20:00 to 02:00 h local time) or during the afternoon (13:00 to $17: 00 \mathrm{~h})$. Conservative estimates of specific growth rates had a range of 0.017 to $0.027 \mathrm{~h}^{-1}$ (generation times of 40.4 to $25.3 \mathrm{~h}$ ). Data for 3 species were sufficiently well-developed to allow calculation of the duration of the recognizable division stages ( 8.3 to $9.5 \mathrm{~h}$ ) and more precise estimates of specific growth rates $\left(0.027\right.$ to $\left.0.039 \mathrm{~h}^{-1}\right)$. Species from the deepest stratum $(80$ to $120 \mathrm{~m})$ displayed quite different reproductive behavior Periodicity was never clearly definable and, when probable, was relatively low in amplitude, although average percentages of dividing cells were similar to those noted for the upper 2 strata.
\end{abstract}

\section{INTRODUCTION}

Interest in the smaller components of the planktonic food-web, e.g. the pico-, nano-, and microplanktonic forms (Sieburth et al. 1978), has been increasing rapidly over the past couple of decades (Laval-Peuto et al. 1986). Driven initially by largely theoretical considerations that small body size and simple life cycles would result in relatively large contributions to total community productivity and carbon transfer, these studies quickly demonstrated that the microzooplankton were ubiquitous and often very abundant in both coastal and oceanic waters (Beers \& Stewart 1967. Beers et al. 1975). More recently, epifluorescence techniques have led to an appreciation of the large populations of nanoplanktonic ciliates (Sherr et al. 1986) and nano- and pico-planktonic flagellates (both heterotrophic and autotrophic), bacteria, and cyanobacteria in those communities (e. g. Landry et al. 1984). Considerable interest has been focused on the 'microbial loop' (Azam et al. 1983) of bacteria, flagellates, and ciliates, specifically questioning the role of that planktonic sub-system in providing either a respiratory 'sink' for autotrophically fixed carbon or a 'link' between

\footnotetext{
- Present address: Biology Department, Washington College, Chestertown, Maryland 21620. USA
}

these minute forms and the larger components of the traditional food-chains (Laval-Peuto et al. 1986).

Simultaneously with these investigations of the composition of the natural planktonic community, laboratory experiments to describe the feeding, growth, and excretion rates of components of the microbial loop were conducted (Goldman \& Caron 1985, Verity 1985). These experiments generally demonstrated the potential for rapid metabolic rates and supported the speculation that these forms could be extremely important in material and energy flow within the water column. Most recently, great effort has been devoted to determining these rates in relatively undisturbed natural planktonic populations in order to verify or modify laboratory data. Selective filtrations of metabolic inhibitors have been applied to isolate specific components, visually or isotopically distinct particles have been used in feeding experiments (Heinbokel 1978, Laval-Peuto et al. 1986 and references cited therein), and sophisticated enclosures have been designed to minimize containment effects (Landry \& Hassett 1982, Stoecker et al, 1983). These are all useful techniques; all, however, require manipulation or containment of the studied populations. A certain doubt remains when applying these results to interpret the natural situation.

One technique for determining reproductive rates of protistan populations does not require containment or 
manipulation. The 'frequency-of-dividing-cells' (FDC) technique can be used for those populations which meet a presently rather restrictive list of conditions: (1) single natural populations must be sampled repeatedly, (2) at least 2 successive stages (and preferably 3 or more stages) in the organism's life-cycle must be reliably recognizable, (3) the duration of one or more of those recognizable stages must be known, and (4) any diel periodicity in reproduction must be defined. In practice, these final 2 requirements are related and certain patterns of periodicity can either eliminate the need for duration estimates or determine whether such duration estimates must be obtained from laboratory or other independent experimental means (McDuff \& Chisholm 1982). The technique has been successfully applied to bacteria (Hagström et al. 1979) and phytoplankton (e.g. McDuff \& Chisholm 1982 and references cited therein). Attempts to apply it to planktonic ciliates have been largely limited by an inability to obtain the necessary data defining the duration of stage(s) (Coats \& Heinbokel 1982, Heinbokel \& Coats 1986). Heinbokel (1987), however, showed that several species of oceanic tintinnine ciliates in surface waters of the North Pacific Ocean were characterized by a strong diel periodicity in reproduction which suggested that the necessary duration estimates could be derived directly from appropriate field samples. Sample size in that study, however, was too small to allow precise estimates of population reproductive rates; conservative estimates suggested that generation (doubling) times were on the order of 1 to $1.5 \mathrm{~d}$.

Arrangements, therefore, were made to obtain additional material during the second field season of the Plankton Rate Processes in Oligotrophic OceanS (PRPOOS) project, August to September 1984. Sampling was improved during this cruise by use of larger nets rigged for opening/closing operation to collect samples from a series of discrete depth strata. The goal of this sampling program several hundred kilometers north of Hawaii was to obtain a set of samples suitable for a fuller application of the FDC technique to the assemblage of tintinnine ciliates in these oligotrophic waters. In short: (1) is the strong diel periodicity observed in 1982 (Heinbokel 1987) reliably characteristic of this region? (2) Would it characterize other tintinnine species in these waters? (3) Is it consistent throughout the water column? (4) Could more accurate estimates of specific growth rates be made after an improved sampling program?

\section{MATERIALS AND METHODS}

Sampling. Vertically stratified sets of plankton samples were obtained on several occasions during a cruise
(Alcyone III; August to September 1984, RV 'Melville') to the 'Climax' station north of Hawaii (ca 28 to $29^{\circ} \mathrm{N}$ 154 to $155^{\circ} \mathrm{W}$.). An extended oceanographic station was occupied at that site during the period 19 August to 6 September 1984 . While on that station, a number of sampling and experimental programs were conducted. The overall goal of the cruise was to utilize a variety of techniques to define the rates of primary production at a site characteristic of the oceanic basins and to resolve the previously conflicting estimates of that productivity (e.g. Laws et al. 1984 and references cited therein). Only those sampling programs and resultant data which are immediately germane to my specific project will be described here.

Continuous vertical profiles of incident light, in vivo fluorescence, temperature, and conductivity were made repeatedly during the cruise using a CTD or a bathyphotometer and profiling from the surface to 200 $\mathrm{m}$. Discrete water samples were taken frequently over the same depth interval by rosette-mounted $30 \mathrm{l}$ Niskin bottles; water samples were used for analysis of chlorophyll $a$, particulate carbon and nitrogen, and dissolved nutrients.

Depth-stratified microplankton samples were obtained with a set of opening/closing nets, towed almost vertically. Mouth openings of the nets were circular, 0.5 $\mathrm{m}$ diameter; nets were $2.5 \mathrm{~m}$ long and constructed of Nitex netting of $25 \mu \mathrm{m}$ mesh opening. General Oceanics double-trip mechanisms were used to control the deployment of nets. Nets were rigged so as to be lowered in a reversed, non-collecting orientation. A first messenger opened the nets; tows were made; and then a second messenger caused the nets to be closed with a 'choker line' attached approximately $1 / 3$ of the way down the net. Generally 4 nets were attached to the hydro-wire at $40 \mathrm{~m}$ intervals at each sampling time. The topmost net was lowered to a depth of $40 \mathrm{~m}$; the nets were opened and the wire retrieved at ca $15 \mathrm{~m}$ min $^{-1}$ until the top net reached the surface. The second messenger was dropped to close the nets, and the nets retrieved back on deck, rinsed, and the catch processed. During initial deployments of the nets, swells passing the stationary ship tended to wrap the nets around the hydro-wire, preventing proper operation of the double-trip mechanisms. Accordingly, the ship was kept slightly under way during subsequent samplings, resulting in a small (generally $\leq 10^{\circ}$ ) wire angle during the sampling. Tows were, therefore, slightly oblique and the depth intervals sampled slightly less than the targeted 0 to $40 \mathrm{~m}, 40$ to $80 \mathrm{~m}, 80$ to $120 \mathrm{~m}$, and 120 to $160 \mathrm{~m}$ intervals. Even sampling underway, net malfunctions were disappointingly common and increased noticeably with increased wave action. Since a malfunctioning trip-mechanism will prevent all lower nets from functioning properly, the most complete set of 
samples was obtained from the 0 to $40 \mathrm{~m}$ interval; progressively less complete sets were obtained from each successively deeper stratum.

Aboard ship, samples were gently rinsed with filtered seawater from the filtering cod-ends of the nets. Samples were made up to $60 \mathrm{ml}$ with filtered seawater and split into three $20 \mathrm{ml}$ aliquots, each being placed into a $22 \mathrm{ml}$ glass scintillation vial. Two aliquots were each fixed with $1 \mathrm{ml}$ additions of $40 \%$ aqueous formaldehyde solution saturated with $\mathrm{CaCO}_{3}$; the third subsample was fixed with a formalin/acridine orange solution (Coats \& Heinbokel 1982).

Sample sets were obtained over 5 separate time intervals. Each planned collecting program was to consist of sets of 4 vertically stratified net-tows $140 \mathrm{~m}$ intervals over the 0 to $160 \mathrm{~m}$ surface layer) repeated at $1.5 \mathrm{~h}$ intervals over a $24 \mathrm{~h}$ period. Problems with equipment, weather and wave action, and conflicting demands on 'wire' and 'ship' time prevented any such ideal sample set from being obtained. The most complete set was obtained over the period 29 to 30 August 1984. Several gaps in those data were filled with materials collected 31 August or 3 September 1984. Successful sampling of the lowest stratum (120 to 160 $\mathrm{m})$ was so infrequent that microscopic analysis of the few samples obtained was not attempted.

Sample/data analysis. Tintinnine ciliates were examined using inverted microscopy with epifluorescent illumination (Heinbokel \& Coats 1986). Subsamples of aliquots fixed with formalin $/ \mathrm{CaCO}_{3}$ were placed into 5 or $10 \mathrm{ml}$ settling chambers, 4,6-diamidino-2phenylindole (DAPI) was added to a final concentration of about $0.5 \mu \mathrm{g} \mathrm{ml}^{-1}$, and the ciliates examined after several hours to allow the cells to settle and the DAPI to penetrate into the cells. Chambers were scanned at $200 \times$ magnification with standard phase-contrast illumination to locate and identify the individual tintinnines. Epifluorescent illumination $(340$ to $380 \mathrm{~nm}$ excitation, $430 \mathrm{~nm}$ barrier filter) at either $200 \times$ or $400 \times$ magnification was then employed to classify the lifecycle stage of each tintinnine. Three stages were enumerated (Coats \& Heinbokel 1982), viz. 'trophic' cells (non-dividing), cells whose macronuclei each contained a 'replication-band' (RB), and 'post-replicationband' (P-RB) cells (including the macronuclear fusion stage and the one or more macronuclear division stages), Cells in at least 2 aliquots were examined from each sample; once 100 cells of a particular species had been classified in a given sample, additional cells of that species were not examined.

The resultant data were examined in 2 ways. First, any diel periodicity was described. Data were plotted as percentage of dividing cells (summing 'replicationband' and 'post-replication-band' stages) as a function of time of day. These data were then tested for the presence of a significant periodicity in timing of cell division. The mean percentage of diving cells was calculated for each species. Each individual sample was then scored as either above $(+)$ or below ( $(-)$ that mean value, resulting in a time-ordered series of scores. In these analyses the time dimension was considered circular or 'wrapped' so that the temporal sequence of scores was not broken at noon as might be otherwise suggested by the figures. Species were deemed to be 'clearly' reproducing with a diel periodicity if all the ' + ' scores occurred together in an uninterrupted sequence; species were considered to be 'probably' synchronous in division if a single ' -' score interrupted an otherwise continuous sequence containing all of the '+' scores (or vice versa).

In addition to being used to objectively identify the presence of diel periodicity, these data were used to define the breadth of the time interval of division and the strength (amplitude) of the periodicity in those species which reproduced synchronously. Linear extrapolations of the data were made and used to define the interval during the day when reproducing cells were more prevalent than average. The mid-point of that interval was arbitrarily chosen as the best description of when cell division occurred. In addition, in those species considered to be clearly or probably periodic in reproduction, the amplitude or strength of that periodicity was estimated by averaging all percentages of dividing cells observed in the '+' scores and subtracting the average percentage of dividing cells observed in the contrasting '-' scores.

The second goal of these analyses was to calculate the actual specific growth rates, $\mu$, $\left(\right.$ time $\left.^{-1}\right)$ and generation (doubling) times for those tintinnines for which the data were adequate. For this analysis both data on the percentages of dividing cells and estimates of the duration of one or more stages in the life cycle are required (e.g. McDuff \& Chisholm 1982). The percentage data are readily available, but estimating the duration term requires clearly defined peaks in percentages of both RB and P-RB stages of the life cycle. Such estimates, therefore, can be made most reliably for those species which are both abundant in the samples and which display relatively strong periodicity in division. Strength of periodicity in the consistently least abundant P-RB stage was the most critical aspect of that latter consideration. In these studies, I made the more detailed analyses only in those cases in which 3 (or 3 of 4 ) adjacent frequencies of post-replication-band stages exceeded the overall mean frequency. For those 3 species which met that latter condition, specific growth rates were calculated as follows. Data on percentages of RB and P-RB stages were graphed separately and the time interval during which those percentages exceeded the mean percen- 
tages was calculated analogously to the procedure described above for the summed percentages. The mid-point of each interval provided an objective estimate of the time of maximum percentage for each stage. The temporal difference between those midpoints in successive stages represents the average duration of the 2 stages, that is, twice that temporal difference equais the duration of both stages together. With this estimate of the combined duration of $\mathrm{RB}$ and $\mathrm{P}-\mathrm{RB}$ stages, the data on total percentage of dividing cells can be used to calculate specific growth rates. Paloheimo (1974) and McDuff \& Chrisholm (1982) independently derived the appropriate formula for this calculation:

$$
\mu=\left[\Sigma \ln \left(1+f_{i}\right)\right] / n D
$$

where $\mu=$ specific growth rate $\left(\mathrm{h}^{-1}\right) ; f_{i}=$ frequency $\left(0 \leq f_{1} \leq 1\right)$ of dividing cells $(\mathrm{RB}+\mathrm{P}-\mathrm{RB})$ in the $i^{\text {th }}$ sample $n=$ number of samples considered over the 24 h period; $D=$ duration of cell division $(\mathrm{RB}+\mathrm{P}-\mathrm{RB})$ in hours. Most effective use of this formula, however, requires that the interval between samples be equal, a condition which could not be met due to logistical constraints during the sampling. Accordingly, linear extrapolations were made between the actual observed frequency values, and 24 extrapolated estimates of frequencies (at $1 \mathrm{~h}$ intervals) used in the calculations.

\section{RESULTS}

\section{Sampling environment}

Vertical profiles of physical and chemical parameters of the environment taken immediately upon arrival and periodically during occupation of the station confirmed that, as expected, the water column was characterized by pronounced thermal and nutrient stratification. Depth of the mixed layer varied between 40 and $60 \mathrm{~m}$ the euphotic zone (>1\% surface light intensity) extended down to between 80 and $90 \mathrm{~m}$, chlorophyli (in vivo fluorescence) peaked between 92 and $122 \mathrm{~m}$, and the nutricline was positioned just below the chlorophyll maximum. Typical values (surface: $160 \mathrm{~m}$ ) were: temperature $\left(25: 18\right.$ to $\left.19^{\circ} \mathrm{C}\right)$, salinity $(35.5$ to $35.6: 35.0$ to $35.1 \%$, nitrate $\left(0\right.$ to $0.1: 2.0 \mu \mathrm{mol} 1^{-1}$ Chlorophyll a values were typically 0.07 to $0.10 \mathrm{ug} \mathrm{l}^{-1}$ at the surface, rising to 0.25 to $0.37 \mathrm{\mu g} \mathrm{l}^{-1}$ in the chlorophyll maximum layer Sampling depths for the series of net-tows were determined from those data. specifically, the 0 to $40 \mathrm{~m}$ stratum was designed to sample the surface mixed zone, and the 80 to $120 \mathrm{~m}$ stratum was designed to sample the chlorophyll maximum zone.

\section{Tintinnine reproductive dynamics}

Fourteen species of tintinnine ciliates were encountered in the net-collected material in sufficient abundance to warrant some level of analysis (Table 1). Diel periodicity in the division process was examined in all of those species (Table 1 ; Figs. 1 to 3 ). In the upper 2 strata (0 to $40 \mathrm{~m}$ and 40 to $80 \mathrm{~m}$ ) diel periodicity was at least probable in every one of the 12 analyses performed. Two of the 8 species analysed in the surface stratum displayed probable periodicity, while the other 6 surface species and all 4 species from the second stratum exhibited clear periodicities in division. In both upper strata the average amplitude of the observed periodicity was relatively high (averaging 46.2 and $45.8 \%$ in the 0 to 40 and 40 to $80 \mathrm{~m}$ strata, respectively). Periodicity was very much less frequent and less strongly defined in the 80 to $120 \mathrm{~m}$ stratum, however. No clear periodicity could be demonstrated for any of these deeper dwelling species and only half of the 6 species analysed displayed probable periodicity. Average amplitude of the probable periodicity in those 3 species $(24.4 \%)$ was also considerably less than for those species found at shallower depth. For all 3 depth strata statistical analyses of these data by means of a Runs-test (Dixon \& Massey 1969) realed that synchrony in the clearly periodic species was consistently significant $(p<0.05)$ except for Eutintinnus brandti ( $\mathrm{p}=$ 0.057 ); synchrony in the probably periodic species was only marginally significant $(0.076 \leq p \leq 0.190)$.

In those species which exhibited clear or probable periodicity in cell division, both the duration of the time during which division-stages were present in greater than average numbers and the timing of the division maximum varied widely The time interval during which reproducing tintinnines are abundant (a function of how 'tightly' phased the population is and/or how long the reproductive stage lasts) varied between 7.8 and $15.0 \mathrm{~h}$. The mid-points of those intervals were mostly concentrated between 20:00 and 02:00 h local time, although 4 of the 15 species had mid-points in the early to mid-afternoon between $13: 00$ and 17:00 h

\section{Specific growth rates}

Data on the frequency-of-dividing-cells (FDC) can be used to calculate specific growth rates in 2 ways. The first, used by Heinbokel (1987), makes use of the maximum FDC observed over the day. If division periodicity is 'tight' and all cells which will divide in that day are encountered in that single sample, the calculation is accurate and does not require an independent estimate of the duration of the division stage(s) observed (McDuff \& Chisholm 1982). If either condition is not 


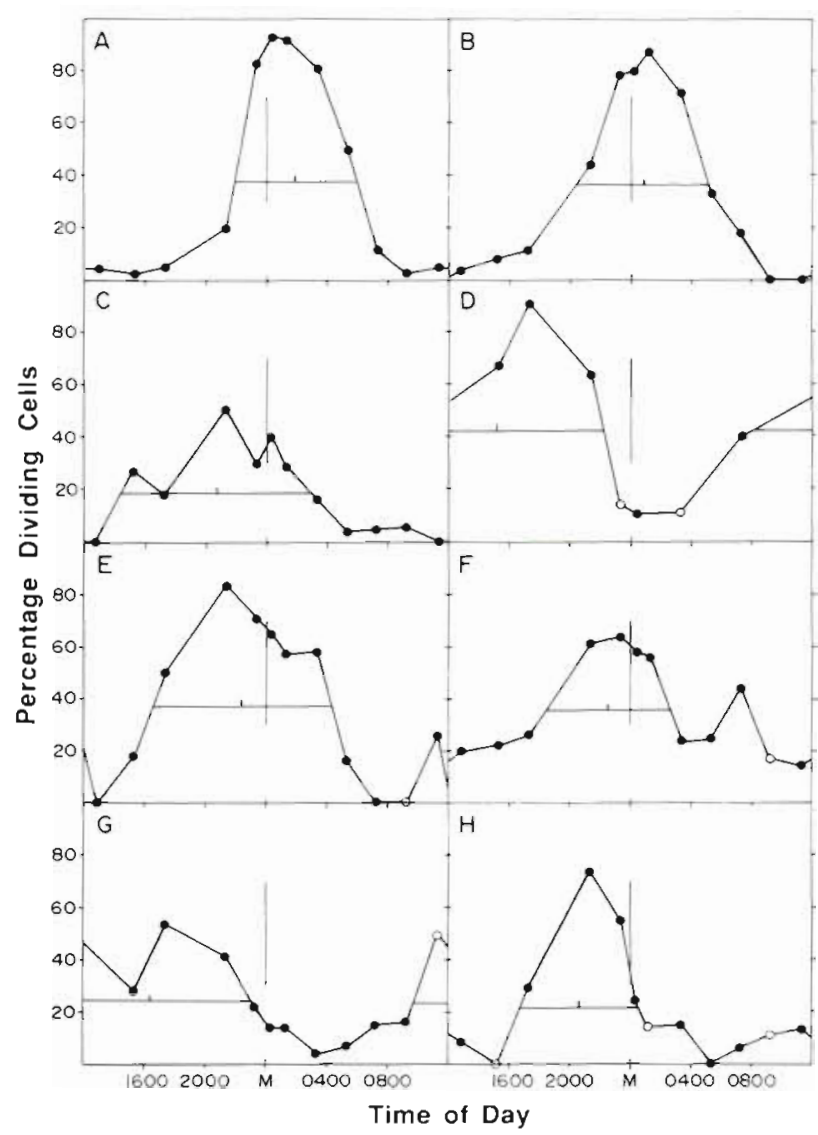

Fig. 1. Diel periodicity of reproduction of tintinnines in 0 to $40 \mathrm{~m}$ depth stratum. (A) Steenstrupiella robusta (mean number of cells examined $=100$ sample $^{-1}$ ); (B) Steenstrupiella steenstrupii (mean $=35.2$ ); $(\mathrm{C})$ Amphorella quadrilineata $($ mean $=23.3) ;$ (D) Eutintinnus brandti $($ mean $=10.9) ;($ E $)$ Xystonella treforti $($ mean $=18.1$ ) ( (F) Protorhabdonella curta $(\text { mean }=31.4)_{i}(\mathrm{G})$ Proplectella globosa $($ mean $=38.9) ;(\mathrm{H})$ Undella sp. (cf. ostenfeldi) (mean = 17.7). (O) Samples containing only 5 to 9 individuals; ( samples of 10 or more individuals. Vertical line marks midnight; horizontal line marks average percentage of dividing cells and defines the period of time in which a greater percentage of cells than average were dividing (vertical 'tick' marks mid-point of that interval) 'Dividing cells' refers to sum of both replication-band and post-replication-band stages as defined in the text

upper $50 \mathrm{~m}$ stratum with a smaller net than used in this study, found pronounced diel periodicity in the reproduction of the 4 most abundant tintinnines. Two of these, Steenstrupiella steenstrupii and Amphorella quadrilineata, were also encountered further north at the 1984 oceanic station; the other 2 coastal species, Steenstrupiella gracilis and Eutintinnus stramentus, are morphologically very similar to their congeners found in the present surface stratum.

In both studies several observations were consistent. The dominant species in these surface layers all displayed clear or probable diel periodicity in cell division. Amplitudes, breadths, and timing of the phased divi-

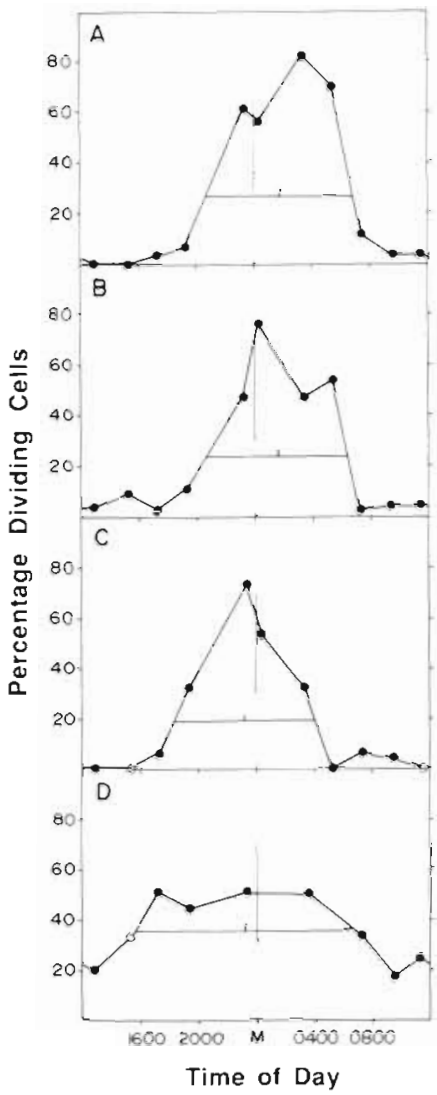

Fig. 2. Diel periodicity of reproduction of tintinnines in 40 to $80 \mathrm{~m}$ depth stratum. (A) Steenstrupiella steenstrupii (mean $=$ 32.7); (B) Amphorella quadrilineata (mean $=27.3$ ); (C) Undella sp. (cf. ostenfeldr) (mean $=19.9$ ) (D) Parundella sp. (cf. longa) $($ mean $=24.8)$. Symbols as in Fig. 1

sion process were extremely similar: Steenstrupiella spp. all displayed high amplitude, narrow breadth periodicity with the division peaks occurring shortly after midnight; Amphorella quadrilineata had a broader, lower amplitude peak in reproduction centered several hours prior to midnight, and Entintinnus spp. displayed high amplitude, broad peaks in reproduction centered several hours after noon. Such consistency in results obtained over 2 yr and several hundred kilometers apart strongly suggests that these results accurately reflect the general nature and timing of tintinnine reproduction in the surface waters of the central North Pacific Ocean, at least during the late summer period. In both studies potentially conservative estimates of population growth rates ranged as high as 1 doubling $\mathrm{d}^{-1}$.

Through (1) use of larger nets, resulting in larger samples permitting statistically valid examination of more species and (2) sampling of 3 distinct depth strata, the present investigation has extended our knowledge and understanding of tintinnine reproduction in several directions. Most simply this study has increased 


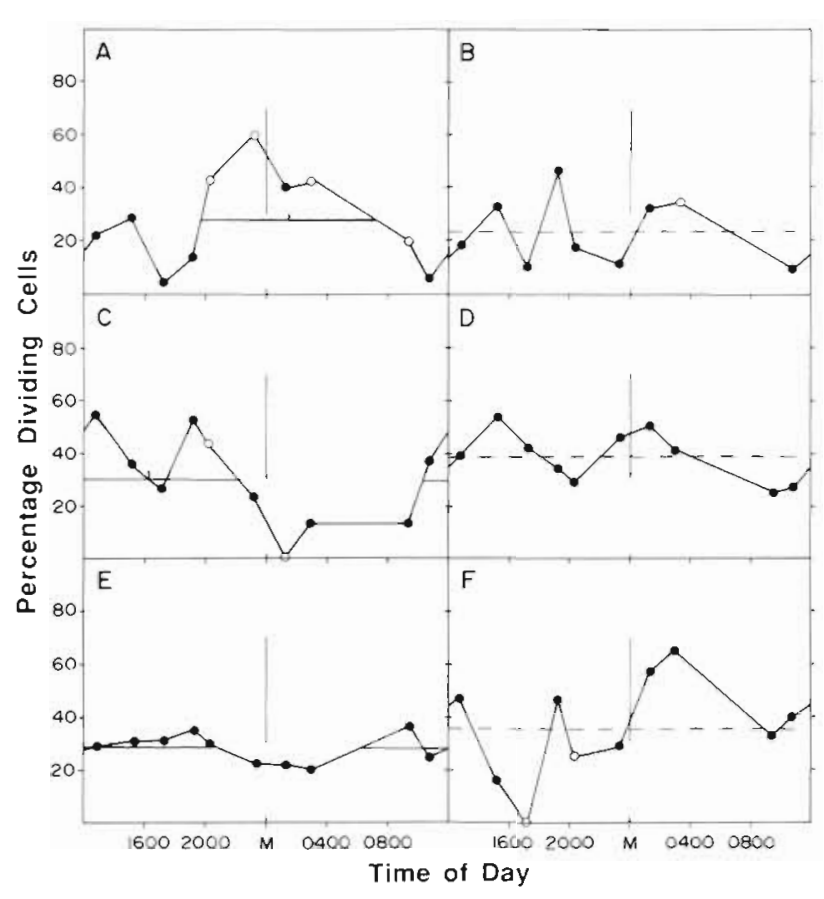

Fig. 3. Diel periodicity of reproduction of tintinnines in 80 to $120 \mathrm{~m}$ depth stratum. (A) Amphorella quadrilineata (mean = 13.6); (B) Proplectella sp. (mean = 18.8); (C) Canthariella brevis (mean $=22.4)$; (D) Dadayiella cuspis (mean $=30.3)$; $(\mathrm{E})$ Salpingella sp. $(270 \mu \mathrm{m})$ (mean $=29.6)$; $(\mathrm{F})$ Salpingella sp. $(100 \mu \mathrm{m})($ mean $=15.7)$. Symbols as in Fig. 1; dashed horizontal lines mark average percentage of dividing cells for species with no discernible periodicity in division

from 4 to 16 the number of species of oceanic tintinnines for which we now have data. Diel periodicity in the reproduction of shallow-living species does, indeed, appear to be the rule at this time of year, although there is considerable variability in the timing and breadth of the reproductive peaks. One of the points of uncertainty in the earlier study (Heinbokel 1987) concerned the lack of periodicity noted when the reproductive dynamics of the total assemblage of tintinnines (other than the 3 dominant species) were considered. It was impossible in that earlier project to discriminate from 2 possible explanations, i. e. a general lack of periodicity in the less common species or significant periodicity in individual species but with variable timing so that the integrated reproductive effort appeared aperiodic. The present data strongly support the latter explanation, since no aperiodic species (of 9 examined in 12 analyses) was identified in the 2 shallowest strata.

In addition to more species to analyse, the larger samples also resulted in examinations of more individuals in the dominant species. One species, Steenstrupiella robusta, was sufficiently abundant that 100 individuals were analysed in each of the surface samples. The statistical target of 100 individuals sample ${ }^{-1}$ has been common in previous coastal and Antarctic studies (Coats \& Heinbokel 1982, Heinbokel \& Coats 1986) but had proven unattainable in the previous oceanic effort (Heinbokel 1987). Two other species displayed reproductive characteristics that made them amenable to a more appropriate estimation of population growth rate. In all 3 cases the growth rates calculated by the formula of Paloheimo (1974) and McDuff \& Chisholm (1982) were, as expected, greater than the conservative estimates based only on the maximum observed frequency of dividing cells. The differences between the 2 estimates for the 2 species of Steenstrupiella, however, were very slight, supporting the expectation that, with strong reproductive phasing, the 2 approaches are nearly equivalent. Xystonella treforti was characterized by a somewhat broader, less intense, periodicity that led to substantial differences between the 2 estimates of growth rate. While such differences should be expected as reproductive phasing weakens, the analysis of $X$. treforti points out another worrisome aspect of these analyses. The Paloheimo (1974) approach to estimating growth rate is critically dependent on the precise definition of the duration of the recognizable reproductive stage(s). In any species where that estimate is uncertain, the population growth rate will be equally uncertain. $X$. treforti presents an excellent example of that problem. The breadth of the P-RB stage was estimated to be $6.5 \mathrm{~h}$ with a mid-point at $02: 20 \mathrm{~h}$ local time (Fig. $4 \mathrm{c}$ ). The resultant duration of the reproductive phases of the tintinnine's life cycle (RB + P-RB stages) was estimated to be $8.3 \mathrm{~h}$, leading ultimately to a calculated generation time of $18 \mathrm{~h}(\mu=$ $0.039 \mathrm{~h}^{-1}$ ). Such a growth rate seems very rapid for one of the largest species of tintinnine in an extremely oligotrophic environment, but an increase in the temporal separation of the mid-points of the 2 reproductive stages of less than $1.5 \mathrm{~h}$ would result in a calculated generation time now greater than 24 h, an increase of ca $33 \%$ over the original estimate. Without very precise data on the frequencies of the 2 reproductive phases, especially the less abundant P-RB stages, such errors will be very likely to occur but be very difficult to evaluate since, (unlike the conservative result of errors associated with the maximum frequency approach) these errors in estimated duration can be in either direction.

One of the important advances in this study was in the opportunity to collect populations from several depth strata. As noted above, the 2 upper strata were similar to each other and to the surface stratum sampled by Heinbokel (1987). The third stratum (80 to 120 $\mathrm{m})$, however, was different in a number of ways. This layer was beneath the surface mixed layer, was mostly below the euphotic zone ( $>1 \%$ surface irradiance), and encompassed a chlorophyll maximum zone in which the chlorophyll a concentrations exceeded the 
Table 2. Specific growth rates of tintinnine ciliates from the central North Pacific Ocean

\begin{tabular}{|c|c|c|c|}
\hline \multirow[t]{2}{*}{ Depth } & \multirow[t]{2}{*}{ Species } & \multicolumn{2}{|c|}{ Specific growth rate $(\mu)_{i} G T^{\circ}$} \\
\hline & & Maximum FDC ${ }^{b}$ & Total FDC' \\
\hline \multicolumn{4}{|l|}{$0-40 \mathrm{~m}$} \\
\hline & Steenstrupiella robusta & $0.027 h^{-1} ; 25.3 h$ & $0.029 \mathrm{~h}^{-1}: 23.7 \mathrm{~h}$ \\
\hline & S. steenstrupii & $0.026 \mathrm{~h}^{-1} ; 26.6 \mathrm{~h}$ & $0.027 \mathrm{~h}^{-1}: 25.4 \mathrm{~h}$ \\
\hline & Amphorella quadrilineata & $0.017 \mathrm{~h}^{-1}: 40.4 \mathrm{~h}$ & \\
\hline & Eutintinnus brandti & $0.027 \mathrm{~h}^{-1}: 25.7 \mathrm{~h}$ & \\
\hline & Xystonella treforti & $0.025 \mathrm{~h}^{-1} ; 27.5 \mathrm{~h}$ & $0.039 \mathrm{~h}^{-1}{ }_{i} 18.0 \mathrm{~h}$ \\
\hline & Protorhabdonella curta & $0.021 \mathrm{~h}^{-1} ; 33.6 \mathrm{~h}$ & \\
\hline & Proplectella globosa & $0.018 \mathrm{~h}^{-1} ; 39.1 \mathrm{~h}$ & \\
\hline & Undella sp. (cf. ostenfeldi) & $0.023 \mathrm{~h}^{-1} ; 30.4 \mathrm{~h}$ & \\
\hline \multicolumn{4}{|c|}{$40-80 \mathrm{~m}$} \\
\hline & S. steenstrupii & $0.025 h^{-1} ; 27.8 \mathrm{~h}$ & \\
\hline & A. quadrilineata & $0.024 \mathrm{~h}^{-1} ; 29.4 \mathrm{~h}$ & \\
\hline & Undella sp. (cf. ostenfeldi) & $0.023 \mathrm{~h}^{-1} ; 30.4 \mathrm{~h}$ & \\
\hline & Parundella sp. (cf. longa) & $0.017 \mathrm{~h}^{-1} ; 40.4 \mathrm{~h}$ & \\
\hline \multicolumn{4}{|c|}{$80-120 \mathrm{~m}$} \\
\hline & A. quadrilineata & $0.020 \mathrm{~h}^{-1} ; 35.4 \mathrm{~h}$ & \\
\hline & Proplectella sp. & NA & \\
\hline & Canthariella brevis & $0.018 \mathrm{~h}^{-1} ; 38.5 \mathrm{~h}$ & \\
\hline & Dadayiella cuspis & $\mathrm{NA}$ & \\
\hline & Salpingella sp. $(270 \mu \mathrm{m}$ long $)$ & $0.013 h^{-1} ; 52.8 h$ & \\
\hline & Salpingella sp. (100 um long) & NA & \\
\hline \multicolumn{4}{|c|}{${ }^{a} \mu\left(\mathrm{h}^{-1}\right)$; GT: generation (doubling) time (h) } \\
\hline \multirow{2}{*}{\multicolumn{4}{|c|}{$\begin{array}{l}{ }^{\mathrm{b}} \text { Conservative estimate of specific growth rate/generation time calculated by use of maximum observed FDC } \\
\text { recognizable reproductive stages }\end{array}$}} \\
\hline & & & \\
\hline \multicolumn{4}{|c|}{ NA: calculation not appropriate in aperiodic species } \\
\hline
\end{tabular}

surface values by 3 to 5 times. The species composition was also quite different from that of the upper strata and the reproductive dynamics were quite different in a number of aspects. Although the mean frequencies of dividing cells were similar in all 3 strata (ca 20 to $40 \%$; Table 1), the tintinnine species from 80 to $120 \mathrm{~m}$ were notable in the weakness or absence of diel periodicity in the reproductive process. Only 3 of the 6 dominant species exhibited even probable periodicity and that periodicity was rather wide in breadth and definitely low in amplitude compared to the upper strata (Fig. 3).

There are, therefore, striking differences in the patterns of diel periodicity of cell division in populations of oceanic tintinnine ciliates from surface populations and from the depth of the chlorophyll maximum layer. Several explanations for these distinct differences can be discussed although no definitive resolution of the differences can be offered at this time. Heinbokel (1987) pointed out that laboratory studies with other taxa of ciliates had indicated that any of several stimuli could result in a phased diel cell division pattern only if growth was maintained at rates slower than 1 division $\mathrm{d}^{-1}$. Perhaps the populations found within the relatively enriched chlorophyll maximum layer are able to maintain growth rates in excess of 1 doubling $\mathrm{d}^{-1}$ (as is presumably the case with estuarine and Antarctic populations), thus preventing the entrainment of the division process to a diel stimulus. Alternatively, at least 2 of the stimuli that can be used to entrain laboratory populations, light and temperature changes, would be expected to be extremely attenuated at depths of 80 to $120 \mathrm{~m}$. Even if the populations are growing sufficiently slowly to be amenable to phasing, no entraining signal would, therefore, be reaching them. Finally, and potentially least interesting, since the species composition of the deeper tintinnine assemblage is almost entirely different from the shallower assemblages, it may be that those deeperliving species are simply incapable of diel phasing in division, such that, regardless of environmental conditions or population growth rates, they would not display any diel periodicity in division.

Without being able to estimate durations of division stages for representative species from each stratum, it is impossible to determine at this point whether, in fact, any differences exist in their growth rates. For example, in the present study, if the duration of reproduction is about the same for all species in all strata, then the population growth rates should also be similar, since all strata were characterized by similar average frequen- 


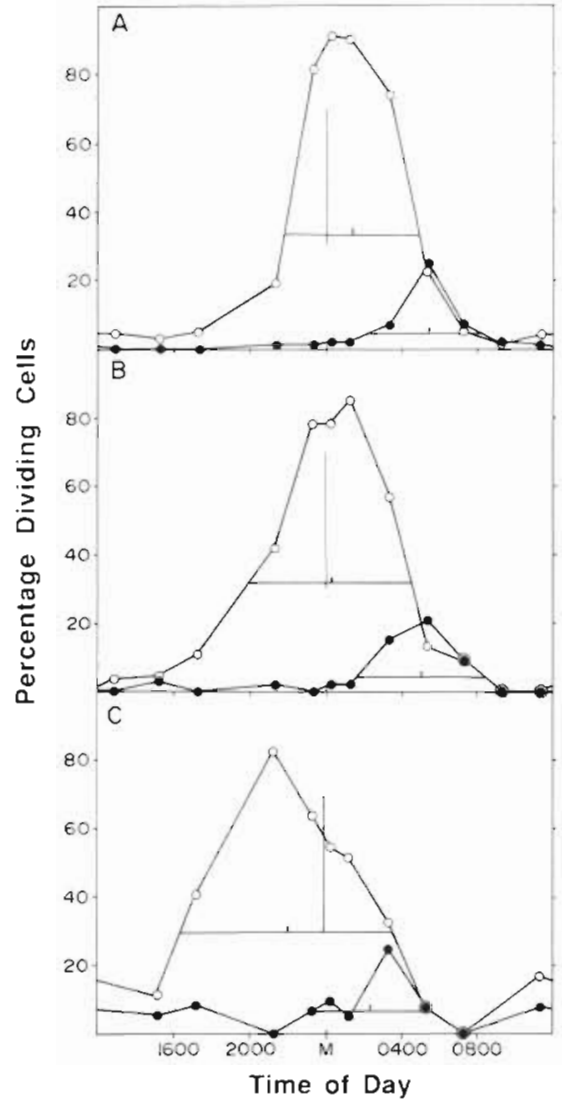

Fig. 4. Percentages of replication-band stages $(0)$ and postreplication-band stages (•) for (A) Steenstrupiella robusta (duration of divison, $D=8.3 \mathrm{~h}$ ); (B) Steenstrupiella steenstrupii $(D=9.5 \mathrm{~h})$; (C) Xystonella treforti $(D=8.3 \mathrm{~h})$. Other symbols as in Fig. 1

cies of dividing cells. Actually, given 2 populations of cells with identical average division frequencies and identical division durations, the aperiodic population would have a faster population growth rate than would the periodic population, although the difference generally would be relatively small.

Although little can be said about the specific growth rates of the deeper tintinnines, the populations in the upper 2 strata were growing at rates similar to those that impressed Heinbokel (1987). Clearly, with conservative estimates of generation times for those 9 species of shallow-living tintinnines almost always in the 24 to $36 \mathrm{~h}$ range, the rapid rates estimated in the earlier study receive considerable support. Heinbokel (1987) commented on the surprisingly rapid growth rates displayed by the tintinnines sampled in 1982; the earlier studies suggested that the tintinnines were growing at rates very similar to those of their phytoplanktonic prey. Those comments are equally valid in the context of this study, with the several dominant species of tintinnines in the oceanic surface layers apparently turning over on a daily basis. Beers et al. $(1975,1982)$ found that tintinnines constituted a relatively insignificant fraction of the oceanic plankton at this site (a finding consistent with the non-quantative impressions gained in this study). Although relatively little of the phytoplanktonic primary production, therefore, would be passing through this group of organisms, the possibility remains that they may constitute an extremely important food resource for larger grazers in these waters, since the vast majority of phytoplanktonic biomass and production is resident in the very small size classes which are unavailable to many of the crustacean grazers (e. g. Nival \& Nival 1976).

Acknowledgements. This research was supported by NSF Grants OCE 82-19171 and OCE 81-20773 (to Dr R. W. Eppley). I appreciate the loan of sampling gear from Dr C. S. Weiler, and the sampling assistance from Dr R. W. Eppley, Ms J. Eppley, Mr E. H. Renger, and the officers and crew of RV Melville. Supporting data were supplied by Drs R. W. Eppley and E. Swift. Dr K. Banse and 2 anonymous reviewers improved this manuscript with their comments.

\section{LITERATURE CITED}

Azam, F., Fenchel, T., Field, J. G., Gray, J. S., Meyer-Reil, L. A., Thingstad, F. (1983). The ecological role of water column microbes in the sea. Mar. Ecol. Prog. Ser 10:257-263

Beers, J. R., Reid, F. M. H., Stewart, G. L. (1975). Microplankton of the North Pacific central gyre. Population structure and abundance, June 1973. Int. Revue ges. Hydrobiol. 60: $607-638$

Beers, J. R., Reid, F. M. H., Stewart, G. L. (1982). Seasonal abundance of the microplankton population in the North Pacific central gyre. Deep Sea Res. 29: 227-245

Beers, J. R., Stewart, G. L. (1967). Micro-zooplankton in the euphotic zone at five locations across the California Current. J. Fish. Res. Bd Can. 24: 2053-2068

Coats, D. W., Heinbokel, J. F. (1982). A study of reproduction and other life cycle phenomena in planktonic protists using an acridine orange fluorescence technique. Mar. Biol. 67: 71-79

Dixon, W. J., Massey, F. J. (1969). Introduction to statistical analysis, 3rd edn. McGraw-Hill, New York

Goldman, J. C., Caron, D. A. (1985). Experimental studies on an omnivorous microflagellate: implications for grazing and nutrient regeneration in the marine microbial food chain. Deep Sea Res. 32: 899-915

Hagström, §., Larsson, U., Hörstedt, P., Normark, S. (1979). Frequency of dividing cells, a new approach to the determination of bacterial growth rates in aquatic environments. Appl environ. Microbiol. 37: 805-812

Heinbokel, J. F. (1978). Studies on the functional role of tintinnids in the Southern California Bight. II. Grazing rates of field populations. Mar. Biol. 47: 191-197

Heinbokel, J. F. (1987). Diel periodicities and rates of reproduction in natural populations of tintinnines in the oligotrophic waters off Hawaii, September 1982. Mar. microb. Food Webs 2: 1-14

Heinbokel, J. F., Coats, D. W. (1986). Patterns of tintinnine abundance and reproduction near the edge of seasonal pack-ice in the Weddell Sea, November 1983. Mar. Ecol. Prog. Ser. 33: 71-80 
Landry, M. R., Haas, L. W., Fagerness, V L. (1984). Dynamics of microbial plankton communities: experiments in Kaneohe Bay, Hawaii. Mar. Ecol. Prog. Ser. 16: 127-133

Landry, M. R., Hassett, R. P. (1982). Estimating the grazing impact of marine microzooplankton. Mar. Biol. 67 : 283-288

Laval-Peuto, M., Heinbokel, J. F., Anderson, O. R., Rassoulzadegan, F., Sherr, B. F. (1986). Role of micro- and nanozooplankton in marine food webs. Insect Sci. Applic. 7: 387-395

Laws, E. A., Redalje, D. G., Haas, L. W., Bienfang, P. K., Eppley, R. W., Harrison, W. G., Karl, D. M., Marra, J. (1984). High phytoplankton growth and production rates in oligotrophic Hawaiian coastal waters. Limnol. Oceanogr. 29: 1161-1169

McDuff, R. E., Chisholm, S. W (1982). The calculation of in situ growth rates of phytoplankton populations from fractions of cells undergoing mitosis: a clarification. Limnol Oceanogr. 27: 783-788

Nival, P., Nival, S. (1976). Particle retention efficiencies of an herbivorous copepod, Acartia clausi (adult and copepodite stages): effects on grazing. Limnol. Oceanogr. 21: 24-38
Paloheimo, J. (1974). Calculation of instantaneous birth rate. Limnol. Oceanogr. 19: 692-694

Porter, K. G., Sherr, E. B., Sherr, B. F., Pace, M., Sanders, R. W. (1985). Protozoa in planktonic food webs. J. Protozoology 32: $409-415$

Sieburth, J. McN., Smetacek, K., Lenz, J. (1978). Pelagic ecosystem structure: heterotrophic compartments of the plankton and their relationship to plankton size fractions. Limnol. Oceanogr. 23: 1256-1263

Sherr, E. B., Sherr, B. F., Fallon, R. D., Newell, S. Y. (1986). Small aloricate ciliates as a major component of the marine heterotrophic nanoplankton. Limnol. Oceanogr. 31: $177-183$

Stoecker, D., Davis, L. H., Provan, A. (1983). Growth of Favella (Ciliata: Tintinnina) and other microzooplankters incubated in situ and comparison to growth in vitro. Mar. Biol. 75: 293-302

Verity, P. (1985) Grazing, respiration, excretion, and growth rates of tintinnids. Limnol. Oceanogr. 30: 1268-1282

This article was presented by Professor K. Banse; it was accepted for printing on June 6, 1988 